\title{
Coping Strategies and Psychological Constitution of Pre-Service and In-Service Teachers
}

Miroslava Lemešová ${ }^{1}$, Elena Brozmanová ${ }^{2}$, Silvia Harvanová ${ }^{3}$, Zlatica Jursová Zacharová , Katarína Minarovičová, Lenka Sokolová ${ }^{6}$

1 Comenius University in Bratislava, Faculty of Education, 59 Račianska St., SK-813 34 Bratislava, Slovakia, lemesova@fedu.uniba.sk

2 Comenius University in Bratislava, Faculty of Education, 59 Račianska St., SK-813 34 Bratislava, Slovakia, brozmanova@fedu.uniba.sk

3 Comenius University in Bratislava, Faculty of Education, 59 Račianska St., SK-813 34 Bratislava, Slovakia, harvanova@fedu.uniba.sk

4 Comenius University in Bratislava, Faculty of Education, 59 Račianska St., SK-813 34 Bratislava, Slovakia, zacharova@fedu.uniba.sk

5 Comenius University in Bratislava, Faculty of Education, 59 Račianska St., SK-813 34 Bratislava, Slovakia, minarovicova@fedu.uniba.sk

6 Comenius University in Bratislava, Faculty of Education, 59 Račianska St., SK-813 34 Bratislava, Slovakia, sokolova@fedu.uniba.sk

Annotation. The study aims to investigate coping strategies used by pre-service and inservice teachers $(\mathrm{N}=610)$ and correlations among coping strategies and psychological constitution variables of pre-service teachers $(\mathrm{N}=349)$. Preferred coping styles differ across career levels but teachers in our sample choose mostly positive and productive coping strategies. Coping strategies classified as negative correlated negatively with psychological constitution variables.

Keywords: pre-service teachers, in-service teachers, stress, coping, coping strategies, psychological constitution, cross-sectional research.

\section{Introduction}

Teachers often embark upon their careers with enthusiasm, the aspiration to use a democratic or non-directive approach, and a tendency to work innovatively. These 
individuals are motivated by the desire to be part of pupils' lives and to bring about positive changes (Richards, 2012; Rots et al., 2010). However, teachers soon discover that they need to juggle a variety of tasks and duties: classroom management, lesson planning, the motivation of pupils, diversity in the classroom, communication with parents, time management, discipline problems, professional development, and administrative overload (Hong, 2011; Struyven \& Vanthournout, 2017; Chaaban \& Du, 2017; Aldrup et al., 2018). The teaching profession brings time pressure and is physically, emotionally, cognitively, and socially demanding; the first few years in this occupation are particularly challenging (Dias-Lacy \& Guirguis, 2017; Roness, 2011). Distance education due to the COVID-19 pandemic is a new challenge in the teaching profession. Based on the current studies, virus COVID-19 has far-reaching effects in the field of education (Huber \& Helm, 2020) and the teachers' work. During the pandemic, teachers experienced medium to high levels of stress and they applied more functional coping strategies than dysfunctional ones when they attributed the causes of their constraints to external factors (Klapproth et al., 2020). An individual's disposition and abilities to cope with challenging situations are related to variables of a psychological constitution (Hossiep et al., 2007). Teachers with higher scores in emotional stability, resilience, and self-confidence are more likely to cope with stress and burden. Their ability to cope with the demands of their profession influences the areas like job satisfaction, success in the profession, and their decision to remain a teacher. Many teacher training graduates never become teachers (Horvath et al., 2018; Kyriacou \& Kunc, 2007), or they leave the profession during the first five years (Gray \& Brauen, 2013; Johnson \& Birkenland, 2003; Le Cornu, 2013). One of the reasons for leaving early is that teachers find the profession much more demanding than they had expected (Hobson \& Malderez, 2005; Struyven \& Vanthournout, 2017).

The study presents the data collected as a part of robust research focused on the formation and development of professional vision among pre-service teachers related to their personality profiles and the effect of their pre-gradual teacher training. It is a cross-sectional study and investigates teachers at a specific point of time and level of their teaching career (pre-service teachers and in-service teachers). The goal of our research was to investigate typical coping strategies, the differences in coping strategies based on the career level and specialization (teaching for the primary or secondary level of education), and the correlations of coping strategies and psychological constitution variables in the pre-service teacher's sample. For the purpose of this study, we use the term "junior pre-service teachers" or student teachers studying at Bachelor's level, "senior pre-service teachers" for student teachers studying at Master's level, and "in-service teachers" for those who finished their teacher training and work in schools. Teachers for the secondary level of education work with pupils aged from 11 to 19 and primary teachers work with younger children (aged from 5 to 11). The following research questions were posed: a) Are there any differences in coping strategies across career levels? $b$ ) Are there any differences 
in coping strategies between primary and secondary school teachers? c) How do coping strategies relate to the psychological constitution variables?

\section{Stress and Coping in the Teaching Profession}

Compared to other occupations, teachers experience the highest levels of stress, and job dissatisfaction (Lomas et al., 2017). This is even the case in countries where teaching is a respected and well-remunerated occupation. The term "teacher stress" was probably coined in the 1980s by Kyriacou, who characterized it "as the teacher's experience of negative emotions such as anxiety, frustration, tension, anger or depression, in response to the demands and pressures they face in their work as a teacher" (Kyriacou, 2015, 72). If the demands exceed teachers' ability to cope with the situation, they experience stress, which could be caused by various sources. Teachers, regardless of the length of their teaching experience, report the main stressors as being pupils' misbehaviour (Aldrup et al., 2018; Geving, 2007; Lauth-Lebens \& Lauth, 2016; Ouellette et al., 2018), classroom management (Salkovski et al., 2015), time pressure, workload, administrative tasks, and low status in society (Chaaban \& Du, 2017; Kyriacou \& Kunc, 2007). Differences in perceiving and experiencing stress among teachers are often examined in relation to the length of their teaching practice. In this context, the transition into practice is considered as an important period. The findings of the group of novice teachers enable teacher educators to implement innovations into both pre-service teacher training and further professional development.

Novice teachers also report other stressors consistently associated with this particular career group: expectations and the scope of the job; discrepancies between teacher training and real tasks; isolation and lack of support; and a gap between novice teachers' vision of teaching and the realities of the job (Trait, 2008). The Covid-19 pandemic has extended the list of these stressors that teachers have to deal with, including problems caused by technical barriers or teachers' digital skills (MacIntyre et al., 2020; Eickelmann \& Drossel, 2020).

Current research on stress and coping (Aldrup et al., 2018; Fussangel \& Dizinger, 2014; Lauth-Lebens \& Lauth, 2016; Millová, 2008; Spilt et al., 2011) is often based on the transactional model of stress proposed by Lazarus and Folkman (1984). However, there are also other theoretical concepts (e.g., the job demands-resources model (Demerouti et al., 2001). The person-environment relationship is mediated by two important processes: cognitive appraisal and coping (Folkman et al., 1986). An individual's response to a stressful situation depends on subjective interpretation (appraisal) of an external stressor, which consequently activates an emotional reaction. Cognitive appraisal is described as a universal process in which an individual reviews the surrounding events and evaluates their significance for his or her well-being. At the same time, an 
individual evaluates his or her ability to cope with or change the situation (Lazarus, 1993). Coping has two functions: to regulate stressful emotions (emotion-focused coping) and to change the person-environment relation (problem-focused coping) (Folkman et al., 1986). Lazarus (1993) emphasizes that coping is complex and that people use most of these coping strategies in every stressful situation. However, some coping strategies are more stable than those linked to particular stressful contexts. They can also change from one stage of a stressful event to another. The pattern of coping varies according to the type of stressful event, personality factors and other modalities, e.g., subjective well-being, social functioning, or somatic health (Lazarus, 1993).

Researchers have investigated the reasons for student teachers' stress and correlations with job satisfaction (Chaaban \& Du, 2017; Skaalvik \& Skaalvik, 2015), self-efficacy (Klassen \& Chiu, 2010; Hong, 2011; Troesch \& Bauer, 2017; von der Embse et al., 2016), burnout (Lauth-Lebens \& Lauth, 2016), well-being (Gustems-Carnicer \& Calderón, 2012) or personal variables, like emotional intelligence and resilience, etc. (Johnson et al., 2012; Martínez-Monteagudo et al., 2019). Job satisfaction is considered a motivational concept, referring to how teachers generally feel about their jobs (Skaalvik \& Skaalvik, 2015). Teachers are satisfied with their job if they work in a supportive school environment and experience positive social relations with administrators, colleagues, and parents. Time pressure, a heavy workload, and problems with pupil discipline are associated with low levels of job satisfaction (Chaaban \& Du, 2017). Dissatisfied teachers are, therefore, at risk of higher levels of stress and burnout (Klassen \& Chiu, 2010).

Years in service have been shown to have nonlinear relationships with self-efficacy, which increases early in teachers' careers until their mid-career and then falls (Klassen \& Chiu, 2010). According to Troesch and Bauer (2017), self-efficacy has a higher impact on job stress in second-career teachers than in first-career teachers. Second-career teachers were found to be highly satisfied and experienced low levels of job stress compared to first-career teachers. Von der Embse et al. (2016) studied 1242 teachers in the United States. They found that teachers' self-efficacy in student engagement and classroom management had a significant influence on the relationship between sources of stress and job satisfaction. Self-efficacy beliefs also contribute to a teacher's mental health and work as a protective factor against burnout (Lauth-Lebens \& Lauth, 2016). An imbalance between work-related resources and stressors has a negative impact on occupational well-being mainly among novice teachers because it limits fulfilment of the basic psychological need for competence and relatedness with students and colleagues (Aldrup et al., 2018). Teachers' perception of stress is also related to personal variables, such as emotional intelligence, self-esteem, or resilience. Day et al. (2011) believe that rather than focusing on managing stress, it would be advisable to focus on fostering teachers' resilience. Teachers with higher emotional intelligence (those with the capacity to perceive, understand and regulate their own emotions and those of others) can cope with situations in the classroom and are more resilient to their negative consequences. These competencies, along 
with external conditions that support teachers' resilience (e.g., supportive relationships, good school culture and robust professional identity), promote the well-being of teachers and help them to cope with challenging situations (Arnup \& Bowles, 2016; Johnson \& Birkenland, 2003; Johnson et al., 2012; Martínez-Monteagudo et al., 2019).

Researchers have also studied the coping mechanisms that teachers activate to reduce stress. Coping strategies play an important role in the context of teachers' psychological well-being, job satisfaction and self-efficacy. Coping is understood to be cognitive, affective, or behavioural responses used by an individual to deal with problems (Lazarus \& Folkman, 1984; Salkovski et al., 2015). However, coping is not only limited to successful efforts. It includes all purposeful attempts to manage stress (regardless of their effectiveness) and is a response to a stressful event of personal significance, which challenges an individual's resources (Lewis et al., 2011; Salkovski et al., 2015).

Psychologists classify coping strategies either according to their focus (focused on the situation, stressor, reaction, or stress) or according to their effectiveness in influencing the level of stress and/or its consequences. The direction and intensity of the coping effectiveness depend on the situation, type, and intensity of stressors, and an individual's characteristics, e.g., the length of their teaching experience (Janke et al., 2003). This is why we cannot classify an individual strategy as negative or positive. Teachers cope with stress using either palliative or direct-action techniques (Salkovski et al., 2015). Palliative techniques aim to reduce the impact of the stressors (e.g., drinking, smoking, engaging in leisure activities or avoidance behaviour). Direct-action techniques focus on the elimination of the sources of stress, such as taking action to solve the problem. Lewis et al. (2011) conceptualized three coping styles as mediators of teachers' classroom management: social problem-solving (working hard, seeking professional help and social support, joining with others to deal with the problem and spending time with good friends); passive-avoidant coping (including wishing things could be better, blaming oneself, varying eating or sleeping patterns and getting sick); and relaxation (leisure activities, sport or a sense of humour).

Teachers who cope effectively with teaching-related stress usually rely on healthy relationships with family and friends, and feel supported by their relationships (Richards, 2012). A mong other strategies, they use positive attitudes, humour, relaxation, reflection, and leisure activities. The least used coping strategies (Richards, 2012) are drinking alcohol, using prescription drugs, taking a day off and procrastinating. Teachers with productive positive coping strategies tend not to attribute importance to personal inhibiting factors in stressful situations, e.g., lack of energy, work overload or lack of support from colleagues and administrative staff (Salkovski et al., 2015). During distance teaching due to the COVID-19 pandemic teachers were more likely to use functional (e.g.) planning or seeking social support) than dysfunctional coping strategies (e.g., giving up to attempt goals or drinking alcohol) when they tended to attribute the causes of their constraints to external factors (e.g., parents' low motivation or the school's low level of organization). 
The internalisation of the constraints (e.g., complaining about their own level of organization or the low level of digital competence) was related to rather dysfunctional than functional coping strategies (Klapproth et al., 2020).

Some differences in coping strategies among teachers have been found, associated with age and career level. Although novice teachers often experience a heavy workload, they have high hopes for their teaching. In their 2015 study, Skaalvik and Skaalvik found that younger teachers avoided sick leave, whereas middle-aged teachers used sick leave as a strategy for having a short break from work. Senior teachers tended to respond to stress by lowering their ambitions, working less at home, and spending more time exercising and relaxing. Similar results were confirmed by Chaaban and $\mathrm{Du}$ (2017) who found that coping strategies used by novice teachers included mostly direct-action strategies, whereas experienced teachers used both direct-action and palliative strategies. Even novice teachers seemed to have a limited repertoire of coping strategies, developing temporary but sufficient solutions to help them survive the early years of their practice (Le Maistre \& Paré, 2010). According to Gustems-Carnicer and Calderón (2012), there is a significant relationship between coping style and psychological well-being. Their findings indicate that proactive coping strategies involving problem-solving among student teachers have a positive effect on reducing the symptoms of depression, anxiety, and distress.

Coping strategies may have a substantial impact on teachers' job satisfaction, psychological well-being, and ability to cope effectively with challenging situations in the classroom. However, these seem to change across career levels.

\section{Method}

The study presents the partial results of robust quantitative research focused on the formation and development of professional vision among pre-service teachers related to their personality profiles and the effect of their pre-gradual teacher training. The data were collected in a cross-sectional type of research design during three years using a set of questionnaires, analysis of narratives, and eye-tracking data methods. The goal of our research was to investigate the most common coping strategies used by teachers of different career levels and teaching specializations and the correlations of coping strategies and psychological constitution variables in the pre-service teachers' sample.

\section{Participants}

The participants $(N=610)$ were junior pre-service teachers $(n=253)$, studying the first or second year of Bachelor teacher training programme, senior pre-service teachers $(n=181)$, studying the first or second year of Master teacher training programme and in-service teachers $(n=176)$, who finished their teacher training and worked in schools. The average age of the sample was $26.63(S D=8.09, \min =18, \max =62)$. Most 
participants were female $(n=560)$. At the time of data collection, the pre-service teachers were enrolled in various teacher training programmes for primary and secondary school teachers at the Comenius University in Bratislava. These trainees were recruited during their introductory psychology courses. In-service teachers were teaching at primary, lower, or higher secondary school level and were invited to participate in the study via an e-mail request from the database of schools cooperating with the university. Their average length of teaching practice was 7.47 years $(S D=7.58$, $\min =1, \max =36)$. All participants took part in this study voluntarily, without any financial or material reward, and were treated in accordance with the ethical guidelines of the American Psychological Association (APA, 2002).

\section{Instruments}

A Stress Coping Style Questionnaire (SVF-78) (Janke et al., 2003) was created to assess the ways of processing a stressful situation. This consists of 78 items with a five-point scale ranging from 0 (not at all) to 4 (very likely), e.g. "In a situation when I am hurt by something or someone, upset, or out of balance, I try to focus my thoughts on something else". The questionnaire was standardized in a Czech adult sample $(N=246)$, used in both career counselling and research (Alcar et al., 2011; Peterková et al., 2017). The items are divided into 13 subscales, which are grouped together into five categories: Positive Strategies of Devaluation (Playing Down and Guilt Denial); Positive Strategies of Distraction (Distraction from the Situation and Substitutional Satisfaction); Positive Strategies of Control (Situation Control, Reaction Control, and Positive Self-Instruction); Negative Strategies (Flight Tendency, Rumination, Resignation, and Self-Accusation); and Rarely Occurring Strategies (Need for Social Support and Active Avoidance). The subscales appeared to have adequate internal consistency in our sample (based on Cronbach's alpha and McDonald's omega tests; see Table 1). However, the consistency scores are lower than reported for the general population sample by Janke et al. (2003).

The Bochum Inventory of Professional Personality Characteristics (BIP) (Hossiep et al., 2007) was standardized for both the Slovak and Czech population, consisting of 196 items (e.g., When I meet strangers, I can easily find a topic for conversation.) grouped into 14 personality dimensions. This inventory is especially used in German-speaking countries for counselling and research relating to the professional development of teachers (Frey, 2006; Greimel-Fuhrmann \& Schwarzl, 2009; Mücke et al., 2006). For the purpose of this study, the BIP questionnaire was administered to 349 pre-service teachers from the overall sample and their results in three dimensions were used to investigate the relationship between psychological constitution (Emotional Stability, Resilience, and SelfConfidence) and coping strategies. In this instrument, Emotional Stability is described as the ability to control emotional reactions and it is similar to Neuroticism as defined in the "Big Five" or Eysenck's personality model. Resilience is a dimension measuring selfevaluation related to the ability to cope with stress, and Self-Confidence is characterized 
as confidence in one's abilities. All three subscales had adequate reliability expressed by internal consistency scores (Table 1).

Table 1

SVF78 and BIP Subscales Descriptive Statistics and Reliability

\begin{tabular}{|c|c|c|c|c|c|c|c|c|c|}
\hline \multirow[t]{2}{*}{ Variables } & \multicolumn{5}{|c|}{$\begin{array}{l}\text { Pre-service and in-service } \\
\text { teachers }\end{array}$} & \multicolumn{3}{|c|}{$\begin{array}{c}\text { Standardization } \\
\text { sample }\end{array}$} & \multirow[t]{2}{*}{$d$} \\
\hline & $\mathrm{N}$ & M & SD & $\alpha$ & $\omega$ & $\mathrm{N}^{*}$ & $\mathbf{M}^{*}$ & $\alpha^{*}$ & \\
\hline Playing Down (SVF78) & 610 & 1.70 & .18 & .83 & .86 & 246 & 1.58 & .90 & .167 \\
\hline Guilt Denial (SVF78) & 610 & 1.81 & .28 & .78 & .79 & 246 & 1.79 & .83 & .038 \\
\hline $\begin{array}{l}\text { Distraction from the Situation } \\
\text { (SVF78) }\end{array}$ & 610 & 2.27 & .15 & .73 & .74 & 246 & 1.97 & .77 & .468 \\
\hline $\begin{array}{l}\text { Substitutional Satisfaction } \\
\text { (SVF78) }\end{array}$ & 610 & 1.92 & .45 & .83 & .84 & 246 & 1.49 & .86 & .532 \\
\hline Situation Control (SVF78) & 610 & 2.83 & .22 & .76 & .76 & 246 & 2.80 & .79 & .057 \\
\hline Reaction Control (SVF78) & 610 & 2.78 & .14 & .68 & .69 & 246 & 2.57 & .80 & .355 \\
\hline $\begin{array}{l}\text { Positive Self-Instruction } \\
\text { (SVF78) }\end{array}$ & 610 & 2.76 & .16 & .84 & .84 & 246 & 2.73 & .84 & .053 \\
\hline Need for Social Support (SVF78) & 610 & 2.68 & .21 & .89 & .90 & 246 & 2.15 & .93 & .632 \\
\hline Active Avoidance (SVF78) & 610 & 2.86 & .21 & .81 & .82 & 246 & 1.99 & .90 & 1.261 \\
\hline Flight Tendency (SVF78) & 610 & 1.91 & .60 & .76 & .77 & 246 & 1.37 & .89 & .853 \\
\hline Rumination (SVF78) & 610 & 2.42 & .14 & .92 & .92 & 246 & 2.52 & .94 & .111 \\
\hline Resignation (SVF78) & 610 & 1.44 & .13 & .79 & .80 & 246 & 1.34 & .88 & .137 \\
\hline Self-Accusation (SVF78) & 610 & 1.90 & .26 & .83 & .83 & 246 & 1.77 & .84 & .161 \\
\hline Emotional Stability (BIP) & 349 & 2.98 & .73 & .84 & .84 & 373 & 3.27 & .84 & .365 \\
\hline Resilience (BIP) & 349 & 3.15 & .80 & .85 & .86 & 373 & 3.57 & .77 & .525 \\
\hline Self-Confidence (BIP) & 349 & 3.23 & .71 & .79 & .80 & 373 & 3.40 & .79 & .229 \\
\hline
\end{tabular}

\section{Procedure and Data Analysis}

The participants were recruited in 2018 and 2019, pre-service teachers were contacted during their introductory psychology courses and in-service teachers were invited to participate via an e-mail request. They were sent a password protected online questionnaire, which contained informed consent. The data was collected and stored anonymously. Kolmogorov-Smirnov test was used to test the normality of data distribution. As the data was not normally distributed for the most of the categories, non-parametric tests 
(Kruskal-Wallis test and Mann-Whitney test) were used to analyse the differences across data sets.

\section{Results}

Table 1 provides means, standard deviations, and internal consistency coefficients for all the variables used in the study, compared to values reported in the standardization samples (Hossiep et al., 2007; Janke et al., 2003). Dominant coping strategies in our sample are Positive Strategies of Control (Situation Control, Reaction Control, and Positive Self-Instruction) and strategies described as Rarely Occurring Strategies (Need for Social Support and Active Avoidance). Comparison with the standardization sample $(N=246$; Janke et al., 2003) indicates that pre-service and in-service teachers differ from the general population, especially in respect of Active Avoidance and Flight Tendency (with a large size effect; $d>.80$ ), and in the Need for Social Support and Substitutional Satisfaction (with a medium size effect). Pre-service teachers' scores in Emotional Stability, Resilience, and Self-Confidence were lower than reported for the standardization sample. For the Resilience subscale, the difference appeared to have a moderate size effect $(d=.525)$, whereas the size effect was low for the other two subscales.

Differences in the use of individual coping strategies were compared across three career levels: junior pre-service teachers who were newly enrolled in the teacher training programme; senior pre-service teachers who were finishing their studies and were at the phase of transition into service; and in-service teachers who had a full-time teaching job in a school (Table 2). In-service teachers tended to use positive coping strategies more often than pre-service teachers. Across career levels, significant differences in coping style were found in five categories of positive strategies: Guilt Denial, Distraction from the Situation, Situation Control, Positive Self-Instruction and Active Avoidance. They were also found in two categories of negative strategies: Resignation and Self-Accusation. Negative strategies were most often used by junior pre-service teachers. The differences appeared to have only a small size effect. 
Table 2

Differences in Coping Strategies Across Career Levels

\begin{tabular}{|c|c|c|c|c|c|c|c|c|c|c|}
\hline & & $\mathbf{N}$ & $\mathbf{M}$ & SD & Min & Max & $\mathbf{H}$ & $p$ & $\eta^{2}$ & $d$ \\
\hline \multirow{3}{*}{ Guilt Denial } & Junior PTs & 253 & 1.67 & .58 & .17 & 3.33 & \multirow{3}{*}{33.571} & \multirow{3}{*}{.000} & \multirow{3}{*}{.052} & \multirow{3}{*}{.468} \\
\hline & Senior PTs & 181 & 1.80 & .61 & .33 & 3.67 & & & & \\
\hline & Teachers & 176 & 2.02 & .63 & .00 & 3.83 & & & & \\
\hline \multirow{3}{*}{$\begin{array}{l}\text { Distraction from } \\
\text { the Situation }\end{array}$} & Junior PTs & 253 & 2.24 & .64 & .50 & 3.67 & \multirow{3}{*}{9.023} & \multirow{3}{*}{.011} & \multirow{3}{*}{.012} & \multirow{3}{*}{.216} \\
\hline & Senior PTs & 181 & 2.21 & .64 & .33 & 3.83 & & & & \\
\hline & Teachers & 176 & 2.39 & .65 & .50 & 4.00 & & & & \\
\hline \multirow{3}{*}{ Situation Control } & Junior PTs & 253 & 2.79 & .63 & .50 & 4.00 & \multirow{3}{*}{6.906} & \multirow{3}{*}{.032} & \multirow{3}{*}{.008} & \multirow{3}{*}{.181} \\
\hline & Senior PTs & 181 & 2.79 & .65 & .83 & 4.00 & & & & \\
\hline & Teachers & 176 & 2.94 & .53 & 1.33 & 4.00 & & & & \\
\hline \multirow{3}{*}{$\begin{array}{l}\text { Positive } \\
\text { Self-Instruction }\end{array}$} & Junior PTs & 253 & 2.72 & .70 & .33 & 4.00 & \multirow{3}{*}{6.995} & \multirow{3}{*}{.030} & \multirow{3}{*}{.008} & \multirow{3}{*}{.182} \\
\hline & Senior PTs & 181 & 2.71 & .69 & .67 & 4.00 & & & & \\
\hline & Teachers & 176 & 2.88 & .59 & .50 & 4.00 & & & & \\
\hline \multirow{3}{*}{ Active Avoidance } & Junior PTs & 253 & 2.82 & .60 & 1.00 & 4.00 & \multirow{3}{*}{11.564} & \multirow{3}{*}{.003} & \multirow{3}{*}{.016} & \multirow{3}{*}{.253} \\
\hline & Senior PTs & 181 & 2.79 & .67 & .00 & 4.00 & & & & \\
\hline & Teachers & 176 & 2.98 & .65 & .67 & 4.00 & & & & \\
\hline \multirow{3}{*}{ Resignation } & Junior PTs & 253 & 1.52 & .72 & .17 & 3.67 & \multirow{3}{*}{6.023} & \multirow{3}{*}{.049} & \multirow{3}{*}{.007} & \multirow{3}{*}{.163} \\
\hline & Senior PTs & 181 & 1.42 & .76 & .00 & 3.50 & & & & \\
\hline & Teachers & 176 & 1.35 & .67 & .00 & 3.33 & & & & \\
\hline \multirow{3}{*}{ Self-Accusation } & Junior PTs & 253 & 2.01 & .80 & .00 & 4.00 & \multirow{3}{*}{16.188} & \multirow{3}{*}{.000} & & \\
\hline & Senior PTs & 181 & 1.91 & .78 & .00 & 3.83 & & & .023 & .309 \\
\hline & Teachers & 176 & 1.71 & .72 & .00 & 4.00 & & & & \\
\hline
\end{tabular}

Notes. $\mathrm{PT}=$ pre-service teachers, only categories with significant differences are displayed. $\mathrm{M}=$ mean, $\mathrm{SD}=$ standard deviation, $\mathrm{H}=$ Kruskal-Wallis test, $\eta^{2}=$ eta squared size effect measure, $d=$ Cohen's d size effect measure

The participants in our sample were teachers in both primary and secondary education. These two specializations may cause different types of classroom situations and different types of occupational stressors, which is why we compared the coping styles among these groups. However, teaching specialization does not seem to have a significant impact on coping strategies. The differences were found in three categories labelled as positive strategies: Distraction from the Situation, Reaction Control, and Active Avoidance (Table 3). Primary teachers tend to use these strategies more often than secondary school teachers, although the differences only appeared to have a small size effect. 
Table 3

Differences in Coping Strategies Across Teaching Specializations

\begin{tabular}{|c|c|c|c|c|c|c|c|c|c|c|}
\hline & & $\mathbf{N}$ & $\mathbf{M}$ & SD & Min & $\operatorname{Max}$ & $\mathbf{U}$ & $p$ & $\eta^{2}$ & $d$ \\
\hline \multirow{2}{*}{$\begin{array}{l}\text { Distraction from } \\
\text { the Situation }\end{array}$} & Primary & 231 & 2.39 & .59 & .67 & 4.00 & \multirow{2}{*}{37257} & \multirow{2}{*}{.002} & \multirow[b]{2}{*}{.016} & \multirow[b]{2}{*}{.252} \\
\hline & Secondary & 379 & 2.20 & .67 & .33 & 3.83 & & & & \\
\hline \multirow[b]{2}{*}{ Reaction Control } & Primary & 231 & 2.85 & .52 & 1.00 & 4.00 & \multirow[b]{2}{*}{39051} & \multirow[b]{2}{*}{.025} & \multirow[b]{2}{*}{.008} & \multirow[b]{2}{*}{.182} \\
\hline & Secondary & 379 & 2.73 & .57 & .33 & 4.00 & & & & \\
\hline \multirow{2}{*}{ Active Avoidance } & Primary & 231 & 2.95 & .61 & 1.00 & 4.00 & \multirow{2}{*}{37517} & \multirow{2}{*}{.003} & \multirow{2}{*}{.014} & \multirow{2}{*}{242} \\
\hline & Secondary & 379 & 2.80 & .65 & .00 & 4.00 & & & & \\
\hline
\end{tabular}

Note. Only categories with significant differences across are displayed.

$\mathrm{M}=$ mean, $\mathrm{SD}=$ standard deviation, $\mathrm{U}=$ Mann-Whitney test, $\eta^{2}=$ eta squared size effect measure, $d=$ Cohen's d size effect measure

Choice of coping strategies might be related to the type of stressful event (situational context) and may vary within a situation. Even Janke et al. (2003) do not consider the ways of dealing with stress to be influenced by other personality variables. We assume that the stability of personal traits affects how individuals experience a challenging situation, evaluate its significance and react to it. Our findings (Table 4) indicate that pre-service teachers with a more stable psychological constitution are those who more frequently choose positive devaluation strategies (Playing Down and Guilt Denial) or positive strategies of control (Reaction Control and Positive Self-Instruction). Their tendency to analyse the intensity of a stressor, decrease the stress level and act constructively might be related to their self-confidence and belief that they are competent enough to cope with the situation. The negative correlations indicate that more frequent choice of negative coping strategies (Flight Tendency, Rumination, Resignation, and Self-Accusation) relates to lower Emotional Stability, Resilience and Self-Confidence. Such self-evaluation may increase stress in the long-term, as the individual does not try to cope with the situation actively and chooses flight or resignation, ruminates, or feels powerless and accuses him or herself. Singular strategies, such as the Need for Social Support and Active Avoidance, are less frequent among pre-service teachers with a more stable psychological constitution. Individuals with a higher level of Emotional Stability and Self-Confidence may tend to confront the challenging situation and try to find a solution, rather than avoid the situation. 
Table 4

Correlations Between Psychological Constitution Variables and Coping Strategies

\begin{tabular}{|c|c|c|c|c|c|c|c|c|c|c|c|c|c|}
\hline SVF78 & 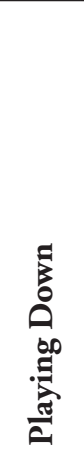 & 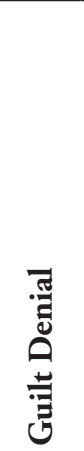 & 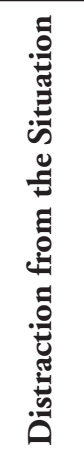 & 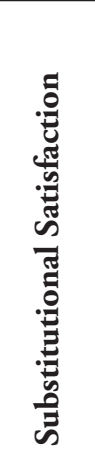 & 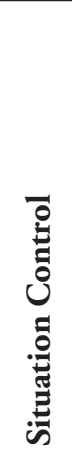 & 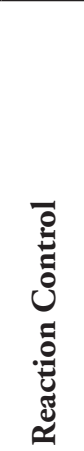 & 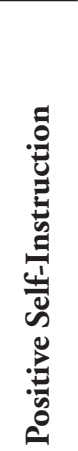 & 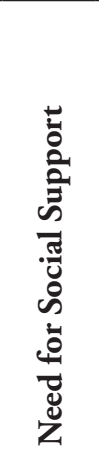 & 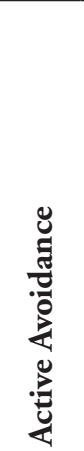 & 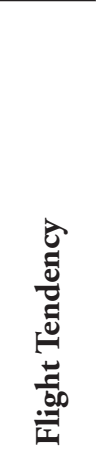 & 泀 & 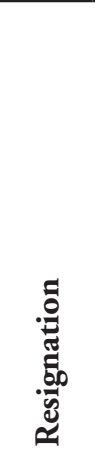 & 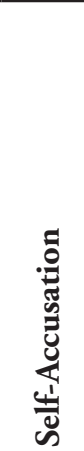 \\
\hline $\begin{array}{l}\text { Emotional } \\
\text { Stability }\end{array}$ & $.61^{* *}$ & $.28^{* *}$ & $.16^{*}$ & -.04 & -.03 & $.22^{* *}$ & $.30^{* *}$ & $-.32^{* *}$ & -.05 & $-.47^{\star \star}$ & $-.62^{* *}$ & $-.52^{\star *}$ & $-.57^{* *}$ \\
\hline Resilience & $.38^{* *}$ & .04 & -.03 & $-.18^{* *}$ & .07 & $.18^{* *}$ & $.30^{* *}$ & $-.32^{* *}$ & -.07 & $-.47^{* *}$ & $-.33^{* *}$ & $-.42^{* *}$ & $-.26^{* *}$ \\
\hline $\begin{array}{l}\text { Self- } \\
\text { Confidence }\end{array}$ & $.48^{* *}$ & $.23^{* \star}$ & .10 & -.10 & .10 & $.16^{* *}$ & $.33^{* *}$ & $-.19^{* *}$ & -.09 & $-.43^{* *}$ & $-.41^{* *}$ & $-.51^{* *}$ & $-.47^{* *}$ \\
\hline
\end{tabular}

Note. $^{* *}$. Correlation is significant at the 0.01 level. ${ }^{\star}$. Correlation is significant at the 0.05 level.

\section{Discussion}

This study illustrates the variability of processing and coping with demanding situations among Slovak pre-service and in-service teachers. We focused on differences in coping strategies across career levels (junior and senior pre-service teachers, and in-service teachers) and specializations (primary and secondary education). Among pre-service teachers, we also investigated the relationship between coping strategies and psychological constitution. The participants reported choosing positive strategies of control in particular (Situation Control, Reaction Control, and Positive Self-Instruction), with rarely occurring coping strategies including the Need for Social Support and Active Avoidance. Choice of positive and productive strategies demonstrates a constructive effort to cope with and take control of a stressful situation, which contributes to teachers' self-efficacy and psychological well-being (von der Embse et al., 2016). However, avoidant emotion-focused coping or behavioural avoidant coping may be strong predictors of mental illness (Gustems-Carnicer \& Calderón, 2012). Differences between teachers and the general sample were found in the Need for Social Support (with a medium size effect), Active Avoidance, and Flight Tendency (both with a large size effect). These tendencies can be interpreted as profession-specific but also gender-specific, as our sample was predominantly female.

Preferred coping styles differ across career levels. Among in-service teachers, we found more frequent use of positive coping strategies, whereas junior pre-service teachers tend 
to use more negative strategies. Differences in the repertoire of strategies used by experienced and novice teachers are expressed not only in their focus, according to Chaaban and $\mathrm{Du}$ (2017), but also in their range. Novice teachers were found to use direct-action strategies (techniques aimed at eliminating sources of stress), while experienced teachers employed both direct-action and palliative strategies (aimed at reducing the impact of stressors). Salkovski et al. (2015) found the most commonly used style of coping among teachers to be social problem-solving. Their participants used productive coping sometimes and non-productive coping occasionally. Teacher gender was also found to be a significant predictor of coping style, with female teachers using social problem-solving more often than male teachers (talking to others, supporting each other, and seeking professional help).

Differences related to teaching specialization do not seem to have a strong impact on preferred coping strategies and significant differences were found only in three strategies with a small size effect. However, we found that more psychologically stable pre-service teachers more frequently choose positive devaluation strategies or positive strategies of control and vice versa. Teachers' confidence in their ability to identify and regulate their own and others' emotional reactions enables them to deal with stress at work better and to choose appropriate coping strategies (Karakus, 2013; Martínez-Monteagudo et al., 2019). In the category of rarely occurring strategies, such as Need for Social Support and Active Avoidance, we found a negative significant correlation with psychological constitution variables. More experienced teachers are likely to have developed an extended, modified repertoire of coping strategies, whereas less experienced teachers often find an effective temporary solution by resorting to coping strategies not considered optimal (Le Maistre \& Paré, 2010). The importance of social support in the teaching profession is highlighted by the fact that low social support at work is often associated with high job stress (Griffith et al., 1999; Johnson \& Birkeland, 2003). We found a negative correlation between the Need for Social Support and psychological constitution variables. In the short-term, perception of one's efficacy in solving a problem without the help of others may lead to a reduction of stress. However, this strategy may boost perceived stress in the long-term, especially among pre-service and novice teachers who lack professional experience. Social support is also one of the conditions facilitating resilience among teachers early in their career (Johnson et al., 2012), as it not only moderates the impact of stressors on well-being but can also influence the appraisal of environmental demands. In the longterm, work overload and lack of support may lead to burnout and leaving the profession early (Salkovski et al., 2015). Based on the current data on coping strategies during the COVID-19 pandemic, the more coping strategies were applied to master the situation. The combination of functional and dysfunctional coping strategies was positively related to stress experience (Klapproth et al., 2020).

Our study does have some limitations. Firstly, it is a sample specification. The participants were pre-service and in-service teachers, and were predominantly women. 
The results cannot, therefore, be generalized to other populations. Our study was crosssectional, which limits the opportunity to understand the development and stability of coping styles and strategies among teachers. Semi-longitudinal design or inclusion of separate samples of novice teachers and expert teachers might help to analyse the differences between those groups. There are also limitations related to the instrument used, the authors (Janke et al., 2003) admit the situational interpretation of some categories.

For further research, it would be useful to investigate coping strategies of pre-service and in-service teachers and their changes caused by the current situation of the COVID-19 pandemic, which according to currently available studies represents a new challenge in the teaching profession (Klapproth et al., 2020). Teachers are experiencing technostress associated with online teaching and their own level of digital competences, as well as legitimate concerns about the full-time form of teaching and possible infection. Currently, we are not aware of the research conducted with a similar design during the COVID-19 pandemic, which would allow a comparison of our data. So far, factors such as inappropriate student behaviour or administrative overload have been studied as correlates of teachers's stress (for example Aldrup et al., 2018; Ouellette et al., 2018), however, the current situation brings new challenges for research at a time when social support as one of the coping mechanisms is considerably limited due to the pandemic.

\section{Conclusion}

Based on our main findings, pre-service teachers differ in their coping strategies from experienced teachers who seem to learn coping strategies. Preferred coping styles differ across career levels, but all teachers from our sample choose often positive and productive strategies to cope with stress. In the sample of pre-service teachers, the correlations of coping strategies and psychological constitution variables indicate that coping strategies classified as negative correlate negatively with psychological constitution variables. We also found a strong positive relationship between psychological constitution and positive strategies of control and devaluation. Emotionally stable, resilient, and confident pre-service teachers seem to choose more positive and productive strategies to cope with stress in their lives.

In the course of their practice, teachers develop a reservoir of more or less effective ways of dealing with stress-provoking situations in school. Understanding teacher stress, its causes, and the relationship between stress and job satisfaction, well-being or self-efficacy, could provide a background for changes, which may reduce teachers' stress. Pre-service teachers and in-service teachers only develop coping strategies for dealing with contextual challenges and, therefore, need more support and practice at university and school levels. We consider it extremely important to bridge the gap between theory and practice during undergraduate teacher education because it is easier to address this 
at an earlier stage than when teachers are professionally employed. Such educational activities could cover the development of a professional vision, extension of teaching practice, training with opportunities to practise problem-solving and other coping strategies related to common sources of school stress (misbehaviour, classroom management, or diversity in the classroom). Improving teachers' coping strategies may be an efficient way of preventing psychological distress in academic and university contexts, but this process has to be continuous throughout a teacher's career.

\section{References}

Aldrup, K., Klusmann, U., Lüdtke, O., Göllner, R., \& Trautwein, U. (2018). Student misbehavior and teacher well-being: Testing the mediating role of the teacher-student relationship. Learning and Instruction, 58, 126-136. https://doi.org/10.1016/j.learninstruc.2018.05.006

American Psychological Association (2002). Ethical principles of psychologists and code of conduct. American Psychologist, 57, 1060-1074.

Arnup, J., \& Bowles, T. (2016). Should I stay or should I go? Resilience as a protective factor for teachers' intention to leave the teaching profession. Australian Journal of Education, 60(3), 229-244. https://doi.org/10.1177/0004944116667620

Balcar, K., Trnka, R., \& Kuška, M. (2011). How many ways to deal with stress? Stress coping factors in the SVF 78. Activitas Nervosa Superior, 53(1-2), 27-34. https://doi.org/10.1007/BF03379931

Day, Ch., Edwards, A., Griffiths, A., \& Gu, Q. (2011). Beyond survival. Teachers and resilience. Key messages from an ESRC-funded seminar series. London: University of Nottingham.

Demerouti, E., Bakker, A. B., Nachreiner, F., \& Schaufeli, W. B. (2001). The job demands-resources model of burnout. Journal of Applied Psychology, 86, 499-512. https://doi.org/10.1037/0021$\underline{9010.86 .3 .499}$

Dias-Lacy, S. L., \& Guirguis, R. V. (2017). Challenges for new teachers and ways of coping with them. Journal of Education and Learning, 6(3), 265-272.

Eickelmann, B., \& Drossel, K. (2020). Schule aufDistanz. Perspektiven und Empfehlungen für den neuen Schulalltag. Eine repräsentative Befragung von Lehrkräften in Deutschland [School at distance. Perspectives and recommendations for the new everyday school life. A representative survey of teachers in Germany]. Düsseldorf, Germany: Vodafone Foundation Germany.

Folkman, S., Lazarus, R. S., Dunkel-Schetter, Ch., DeLongis, A., \& Gruen, R. J. (1986). Dynamics of a stressful encounter: Cognitive appraisal, coping, and encounter outcomes. Journal of Personality and Social Psychology, 50(5), 992-1003. https://doi.org/10.1037/0022-3514.50.5.992 Frey, A. (2006). Methoden und Instrumente zur Diagnose beruflicher Kompetenzen von Lehrkräften. Eine erste Standortbestimmung zu bereits publizierten Instrumenten [Methods and tools for diagnosing teachers' professional competencies. An initial assessment of the instruments that have already been published]. Zeitschrift für Pädagogik [Journal of Pedadogy], 51, 30-46. 
Fussangel, K., \& Dizinger, V. (2014). The challenge of change? The development of all-day schools and its implications for teacher stress. Journal for Educational Research Online, 6(3), 115-133.

Gray, L., \& Brauen, M. (2013). Strategies for longitudinal analysis of the career paths of beginning teachers: Results from the first through fourth waves of the 2007-08 beginning teachers' longitudinal study. Washington: National Center for Education Statistics. http://nces.ed.gov/ pubs2013/2013336.pdf

Greimel-Fuhrmann, B., \& Schwarzl, Ch. (2009). Die Persönlichkeitsentwicklung der Studierenden im ersten Studienjahr des Masterstudiums Wirtschaftspädagogik [The personality development of students in the first year of master's degree in business education]. In:Stock, M. (Ed.): EntrepreneurshipEuropa als Bildungsraum - Europäischer Qualifikationsrahmen [Entrepreneurship - Europe as an educational area - European qualifications framework]. Manz, pp. 151-159.

Griffith, J., Steptoe, A., \& Cropley, M. (1999). An investigation of coping strategies associated with job stress in teachers. British Journal of Educational Psychology, 69(4), 517-531. https:// doi.org/10.1348/000709999157879

Hobson, A. J., \& Malderez, A. (Eds.) (2005). Becoming a teacher: Student teachers' motives and preconceptions, and early school-based experiences during initial teacher training. London: University of Nottingham. https://dera.ioe.ac.uk/5723/1/RR673.pdf

Hong, J. Y. (2011). Why do some beginning teachers leave the school, and others stay? Understanding teacher resilience through psychological lenses. Teachers and Teaching, 18(4), 1-24. https://doi.org/10.1080/13540602.2012.696044

Horvath, M., Goodell, J. E., \& Kosteas, V. D. (2018). Decisions to enter and continue in the teaching profession: Evidence from a sample of U.S. secondary STEM teacher candidates. Teaching and Teacher Education, 71, 57-65. https://doi.org/10.1016/j.tate.2017.12.007

Hossiep, R., Paschen, M., \& Džuka, J. (2007). BIP - Bochumský inventár profesijných charakteristík osobnosti [Bochum inventory of professional personality characteristics]. Praha: Testcentrum.

Huber, S. G. \& Helm, C. (2020). COVID-19 and schooling: evaluation, assessment and accountability in times of crises - reacting quickly to explore key issues for policy, practice and research with the school barometer. Educational Assessment, Evaluation and Accountability, 32, 237-270. https://doi.org/10.1007/s11092-020-09322-y

Janke, W., Erdmann, G., \& Švancara, J. (2003). Strategie zvládání stresu - SVF78 [Coping strategies - SVF78]. Praha: Testcentrum.

Johnson, S. M., \& Birkenland, S. E. (2003). Pursuing a "Sense of Success": New teachers explain their career decisions. American Educational Research Journal, 40(3), 581-617. doi: $\underline{10.3102 / 00028312040003581}$

Johnson, B., Down, B., Le Cornu, R., Peters, J., Sullivan, A., Pearce, J., \& Hunter, J. (2012). Early career teachers: Stories of resilience. The University of South Australia.

Karakus, M. (2013). Emotional intelligence and negative feelings: A gender-specific moderated mediation model. Educational Studies, 39, 68-82. https://doi.org/10.1080/03055698.2012.671514

Klapproth, F., Federkeil, L., Heinschke, F., \& Jungmann, T. (2020). Teachers' experiences of stress and their coping strategies during COVID-19 induced distance teaching. Journal of Pedagogical Research. Advanced online publication. https://doi.org/10.33902/JPR.2020062805 
Klassen, R., \& Chiu, M. M. (2010). Effects on teachers' self-efficacy and job satisfaction: Teacher gender, years of experience, and job stress. Journal of Educational Psychology, 102(3), 741-756. https://doi.org/10.1037/a0019237

Kyriacou, Ch. (2015). Teacher stress and burnout: Methodological perspectives. In J. D. Wright (Ed.), International encyclopedia of social \& behavioral sciences (pp.72-74). https://doi. org/10.1016/B978-0-08-097086-8.92087-7

Kyriacou, Ch., \& Kunc, R. (2007). Beginning teachers' expectations of teaching. Teaching and Teacher Education, 23, 1246-1257. https://doi.org/10.1016/j.tate.2006.06.002

Lazarus, R. S., \& Folkman, S. (1984). Stress, appraisal and coping. New York: Springer.

Lazarus, R. S. (1993). From psychological stress to the emotions: a history of changing outlooks. Annual Review of Psychology, 44, 1-21. https://doi.org/10.1146/annurev.ps.44.020193.000245 Lauth-Lebens, M., \& Lauth, G. W. (2016). Behavioural modification and classroom management skills as protective factors against mental health problems in teachers: A synthesis of research. Journal of Mental Disorders and Treatment, 2(107), 1-6. https://doi.org/10.4172/2471$\underline{271 X .1000107}$

Le Cornu, R. (2013). Building early career teacher resilience: The role of relationships. Australian Journal of Teacher Education, 38(4), 1-16. https://doi.org/10.14221/ajte.2013v38n4.4

Le Maistre, C., \& Paré, A. (2010). Whatever it takes: How beginning teachers learn to survive. Teaching and Teacher Education, 26(3), 559-564. https://doi.org/10.1016/j.tate.2009.06.016

Lewis, R., Roache, J., \& Romi, S. (2011). Coping styles as mediators of teachers' classroom management techniques. Research in Education, 85, 53-68. https://doi.org/10.7227/RIE.85.5

Lomas, T., Medina, J. C., Ivtzan, I., Rupprecht, S., \& Eiroa-Orosa, F. J. (2017). The impact of mindfulness on the well-being and performance of educators: A systematic review of the empirical literature. Teaching and Teacher Education, 61, 132-141. https://doi.org/10.1016/j. $\underline{\text { tate. } 2016.10 .008}$

Martínez-Monteagudo, M. C., Inglés, C. J., Granados, L., Aparisi, D., \& García-Fernández, J. M. (2019). Trait emotional intelligence profiles, burnout, anxiety, depression, and stress in secondary education teachers. Personality and Individual Differences, 142, 53-61.https://doi.org/10.1016/j. paid.2019.01.036

McIntyre, P. D., Gregersen, T., \& Mrecer, S. (2020). Language teachers' coping strategies during the Covid-19 conversion to online teaching: Correlations with stress, wellbeing and negative emotions. System, 94, 1-12. https://doi.org/10.1016/j.system.2020.102352

Millová, K., Blatný, M., \& Kohoutek, T. (2008). Osobnostné aspekty zvládania zátaže [Personality aspects of coping with stress]. E-psychologie, 2(1), 1-8. https://e-psycholog.eu/pdf/millova-etal.pdf Mücke, S., Becher, K., Felger-Pärsch, A., Heusinger, R., Wegner, B., \& Schründer-Lenzen, A. (2006). Das berufsbezogene Selbstkonzept von Lehramtstudierenden der Primarstufe- Ergebnisse einer schriflichen Befragung im Ein-Gruppen-Pretest-Posttest-Design [The job-related self-concept of primary school teacher training students - results of a written survey in a one-group pretest-posttest design]. In Qualitätssicherung und Reformansätze in der Lehrerbildung [Quality assurance and reform approaches in teacher training]. Postdam: Universität Postdam, pp. 30-48. 
Ouellette, R. R., Frazier, S. L., Shernoff, E. S., Cappella, E., Mehta, T. G., .. \& Atkins, M. S. (2018). Teacher job stress and satisfaction in urban schools: Disentangling individual-, classroom-, and organizational-level influences. Behavior Therapy, 49, 494-508. https://doi.org/10.1016/j. beth.2017.11.011

Peterková, H., Zamastilová, H., Skřivanová, K., Brančíková, D., \& Temoshok, L. (2017). Copingové strategie u českých pacientek k karcinomem prsu [Coping strategies among female czech breast cancer patients]. Československá psychologie, 61(1), 488-501.

Roness, D. (2011). Still motivated? The motivation for teaching during the second year in the profession. Teaching and Teacher Education, 27, 628-638. https://doi.org/10.1016/j. tate.2010.10.016

Rots, I., Aelterman, A., Devos, G., \& Vlerick, P. (2010). Teacher education and the choice to enter the teaching profession: A prospective study. Teaching and Teacher Education, 26, 1619-1629. https://doi.org/10.1016/j.tate.2010.06.013

Salkovsky, M., Shlomo, R., \& Lewi, R. (2015). Teachers' coping styles and factors inhibiting teachers' preferred classroom management practice. Teaching and Teacher Education, 48, 56-65. https://doi.org/10.1016/j.tate.2015.01.016

Skaalvik, E. M., \& Skaalvik, S. (2015). Job satisfaction, stress and coping strategies in the teaching profession. What do teachers say? International Education Studies, 8(3), 181-192. https://doi. org/10.5539/ies.v8n3p181

Spilt, J. L., Koomen, H. M. Y., \& Thijs, J. T. (2011). Teacher well-being: The importance of teacherstudent relationships. Educational Psychology Review, 23(4), 457-477. https://doi.org/10.1007/ $\underline{\text { s10648-011-9170-y }}$

Struyven, K., \& Vanthournout, G. (2014). Teachers' exit decisions: An investigation into the reasons why newly qualified teachers fail to enter the teaching profession or why those who do enter do not continue teaching. Teaching and Teacher Education, 43, 37-45. https://doi. org/10.1016/j.tate.2014.06.002

Tait, M. (2008). Resilience as a contributor to novice teacher success, commitment, and retention. Teacher Education Quarterly, 35(4), 57-75.

Troesch, L. M., \& Bauer, C. E. (2017). Second career teachers: Job satisfaction, job stress, and the role of self-efficacy. Teaching and Teacher Education, 67, 389-398. https://doi.org/10.1016/j. tate.2017.07.006

von der Embse, N. P., Sandilos, L. E., Pendergast, L., \& Mankin, A. (2016). Teacher stress, teachingefficacy, and job satisfaction in response to test-based educational accountability policies. Learning and Individual Differences, 50, 308-317. https://doi.org/10.1016/j.lindif.2016.08.001 


\title{
Būsimųjų ir jau dirbančių mokytojų ịveikos strategijos ir psichologinè būklè
}

\author{
Miroslava Lemešová ${ }^{1}$, Elena Brozmanová ${ }^{2}$, Silvia Harvanová ${ }^{3}$, Zlatica Jursová Zacharová ${ }^{4}$, \\ Katarína Minarovičová, Lenka Sokolová ${ }^{6}$
}
1 Komenskio universitetas Bratislavoje, Edukologijos fakultetas, Račianska g. 59, SK-813 34 Bratislava, Slovakija, lemesova@fedu.uniba.sk
2 Komenskio universitetas Bratislavoje, Edukologijos fakultetas, Račianska g. 59, SK-813 34 Bratislava, Slovakija, brozmanova@fedu.uniba.sk
3 Komenskio universitetas Bratislavoje, Edukologijos fakultetas, Račianska g. 59, SK-813 34 Bratislava, Slovakija, harvanova@fedu.uniba.sk
4 Komenskio universitetas Bratislavoje, Edukologijos fakultetas, Račianska g. 59, SK-813 34 Bratislava, Slovakija, zacharova@fedu.uniba.sk
5 Komenskio universitetas Bratislavoje, Edukologijos fakultetas, Račianska g. 59, SK-813 34 Bratislava, Slovakija, minarovicova@fedu.uniba.sk
6 Komenskio universitetas Bratislavoje, Edukologijos fakultetas, Račianska g. 59, SK-813 34 Bratislava, Slovakija, sokolova@fedu.uniba.sk

\section{Santrauka}

Mokytojo profesija sudètinga, mokytojo darbas nuolat kelia ittampą, todèl gebejimas efektyviai ịveikti kliūtis gali būti svarbus apsauginis profesinio streso ar ankstyvojo pasitraukimo iš profesijos veiksnys. Tyrimo tikslas - ištirti ịveikos strategijas, kurias naudoja būsimieji ir jau dirbantys mokytojai, daugiausia dėmesio skiriant ịveikos strategijų skirtumams karjeros lygmenimis, ịveikos strategijų skirtumams tarp pradinių ir vidurinių mokyklų mokytojų ir įveikos strategijoms, susijusioms su psichologinès būklès kintamaisiais. İveikos strategijos buvo vertinamos naudojant streso ịveikos tipo klausimyną ir Bochumo profesinès asmenybès charakteristikų aprašą, kuris skirtas nustatyti psichologinès būklès ir įveikos strategijų ryšị. Remiantis rezultatais, galima matyti, kad mokytojai savęs kaltinimą naudoja rečiau, o dažniau naudojamas aktyvus vengimas, pozityvus savęs tyrinėjimas, situacijos kontrolè ar atitraukimas nuo situacijos. Nustatyta, kad pradinių klasių mokytojai dažniau naudojasi dėmesio atitraukimo nuo situacijos, reakcijos kontrolès ir aktyvaus vengimo priemonėmis nei mokytojai, dirbantys vidurinèse mokyklose. Koreliacijos tarp ịveikos strategijų ir psichologinès būklès kintamųjų rodo neigiamą ryši su neigiamomis strategijomis. Taigi, supratimas apie ịveikos strategijas mokytojo profesijoje padeda mokytojams mokyti būsimuosius mokytojus kovoti su mokymo metu pasireiškiančiu stresu ir kartu išplèsti savo ịveikos strategijų turimus gebejjimus.

Esminiai žodžiai: būsimieji mokytojai, mokytojai, stresas, įveika, ̣̂veikos strategijos, psichologine būklè, skerspjūvio tyrimai. 